\title{
Hoftebrudd på Sørlandet - forekomst og dødelighet
}

\begin{abstract}
På Sørlandet er forekomst og dødelighet av lavenergibrudd i hoften høy og øker med økende alder. Menn har dårligere overlevelse etter et hoftebrudd enn kvinner.
\end{abstract}

Rundt halvparten av kvinner over 50 år vil i løpet av sin resterende levetid pådra seg et osteoporotisk beinbrudd. I løpet av det første året etter et hoftebrudd dør $25 \%$ av pasientene. Tidligere studier har vist at Norge har den høyeste forekomsten av hoftebrudd i verden. Til nå har vi ikke hatt data fra Sørlandet. Generelt har det vært mangelfulle data knyttet til mortalitet etter hoftebrudd i Norge.

I mitt doktorgradsarbeid identifiserte jeg alle pasienter som i 2004-05 hadde lavenergibrudd i hoften. Alle pasienter hadde minst fem års observasjonsperiode. I samme toårsperiode utførte jeg en prospektiv studie der pasienter med denne type brudd på Sørlandet sykehus Kristiansand ble inkludert og undersøkt i henhold til en standardisert protokoll.

Jeg fant at på Sørlandet er forekomsten av lavenergibrudd $\mathrm{i}$ hoften på samme nivå som i andre geografiske områder i Norge. Dødelighet for pasienter med hoftebrudd er betydelig høyere sammenliknet med befolkningen for øvrig både ett år og fem år etter bruddet. Sammenliknet med kvinner hadde menn en betydelig høyere dødelighet etter hoftebruddet. Komorbiditet synes å øke dødeligheten.

Lavenergibrudd i hoften er et stort helseproblem i Norge, som ledsages av høy morbiditet og dødelighet. Selv om nyere data tyder på redusert forekomst av hoftebrudd også i Norge de siste ti årene, vil antallet av denne type brudd øke med økningen

\section{Andreas P. Diamantopoulos}

andreas.diamantopoulos@sshf.no av antall eldre i tiden fremover.

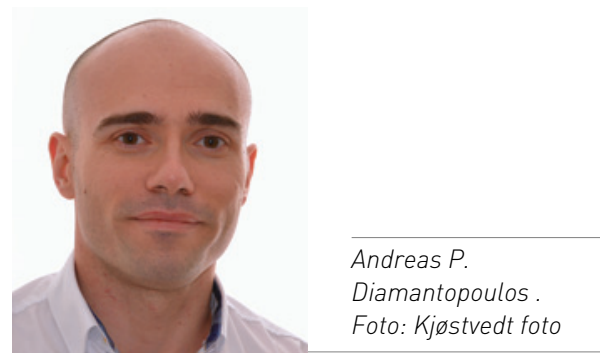

Disputas

Andreas P. Diamantopoulos disputerte for ph.d.-graden ved Norges teknisk-naturvitenskapelige universitet 18.6. 2014. Tittelen på avhandlingen er The epidemiology of fragility hip fracture in Southern Norway: A study on incidence, mortality and predictors of mortality.

\section{Type 2-diabetes hos innvandrere fra Sør-Asia}

\section{Sørasiater med type 2-diabetes ser ut til å være mer insulinresistente enn norske diabetespasienter, og det er hovedsakelig leverens insulin- følsomhet som er affisert.}

Forekomsten av diabetes er høy i sørasiatiske land (Pakistan, India, Bangladesh, Sri Lanka) og hos innvandrere fra denne regionen til vestlige land. I Norge utgjør sørasiater, spesielt pakistanere, en av de største innvandrergruppene. Prevalensen av type 2diabetes er tidligere vist å være høy i denne gruppen også i Norge og vil kunne bli en ikke ubetydelig folkehelseutfordring.

Målet for min doktorgrad har vært å se etter forskjeller i hvordan type 2-diabetes arter seg hos sørasiater og nordmenn.

Jeg har blant annet målt insulinfølsomhet og beregnet leverens glukoseproduksjon. Videre har jeg sett på kroppssammensetning og fettfordeling. Til tross for at den norske gruppen var mer overvektig, hadde sørasia- tene dårligere regulert diabetes. De så ut til å være mer insulinresistente, og det var spesielt leverens insulinfølsomhet som var klart nedsatt. Hos sørasiatene var det også en signifikant negativ korrelasjon mellom mengden visceralt fett og insulinfølsomhet.

Funnene i min studie vil danne grunnlaget for videre studier av leverens glukose- og fettmetabolisme hos sørasiater og vil kunne få betydning for fremtidig valg av behandlingsstrategi i denne pasientgruppen. Behandling spesielt rettet mot insulinresistens i lever kan vise seg å være gunstig.

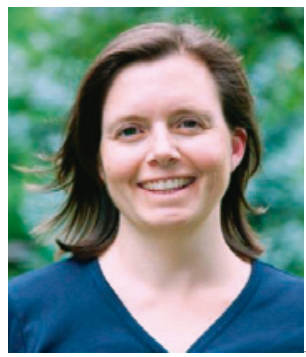

Cecilie Wium. Foto: Birgit Skjelvik, Oslo universitetssykehus

Disputas

Cecilie Wium disputerte for ph.d.-graden ved Universitetet i Oslo 6. 6. 2014. Tittelen på avhandlingen er Clinical and pathophysiological characteristics of type 2 diabetes in South Asian immigrants to Norway.

\section{Cecilie Wium}

cecilie.wium@medisin.uio.no 